\title{
Reconsidering Forty Years after Sino-Japanese Diplomatic Normalization
}

Kazuko MORI

\begin{abstract}
Significantly informed by strategic considerations, the Sino-Japanese diplomatic normalization in 1972 was a side-product of the US-China rapprochement. Due to the speedy negotiations that lasted only five days, the bilateral relations remain fragile, non-institutionalized and personal character-oriented, leaving numbers of issues remain unresolved, such as the handling of the problems left by the previous Sino-Japanese War, the consolation to war victims, and the rebuilding of a long-term relationship. Attempts on cooperation and institutionalization between the two countries have been carried out in the 1980s and the 2000s respectively, but the relations significantly deteriorated thereafter due to the antiJapanese demonstrations in 2005 and the fishing trawler collision incident near the Senkaku/Diaoyu Islands in September 2010. As the fierce anti-Japanese demonstrations erupted in China over the Senkaku/Diaoyu Islands territorial dispute in September 2012, the Sino-Japanese relations reached its nadir since the diplomatic normalization of the two countries. This paper discusses forty years of transformations of Sino-Japanese relations, issues that is unresolved after the 1972 negotiations and attempts on institutionalization of cooperative frameworks. In the addendum, this paper also analyzes the anti-Japanese demonstrations in September 2012 and suggests three emergency proposals to avoid the two countries from entering a "new Cold War".
\end{abstract}

\section{Keywords}

Sino-Japanese diplomatic normalization, ODA, strategic dialogue, East China Sea, historical understanding, East Asian new regionalism 


\section{The Transformation of Sino-Japanese Relations over the Forty Years since Normalization}

\section{A Fragile Structure}

September 2012 marked the fortieth anniversary of normalization of diplomatic relations between China and Japan. After five days of tensed negotiations in Beijing, the normalization was finally realized between newly instated Japanese Prime Minister Tanaka Kakuei and Foreign Minister Ohira Masayoshi, and Chinese Chairman Mao Zedong and Premier Zhou Enlai. It had already been twenty seven years since the end of the Sino-Japanese War, and twenty three years since the founding of the People's Republic of China (PRC).

Have Sino-Japanese relations matured enough over the past 40 years? Unfortunately, with the anti-Japanese demonstrations in 2005 and the fishing trawler collision incident near the Senkaku/Diaoyu Islands (called the Diaoyu Islands in China; for convenience, they will be referred to as the Senkaku Islands below) in 2010 and 2012, the bilateral relations has instead become unstable. Moreover, mutual image at the level of public opinion in both countries has been deteriorating.

The author considers that this unstable relationship roots in the structural fragility of Sino-Japanese relations since the normalization. The 1972 normalization, as a matter of fact, left many unresolved problems that have not been addressed ever since. As touched upon in author's book, Sino-Japanese Relations: From Post-WWII to a New Era, Sino-Japanese relations have continued to be a fragile relationship, characterized by lacking of institutions, overemphasis on personal elements, and are affected by sentiment, rather than reasoning. ${ }^{1}$ Also, in addition to these old issues, new problems regarding the Senkaku Islands and the East China Sea have complicated the relations between the two countries.

In the following part, Section 1 reviews the transformations of the basic structure in the bilateral relations over the past forty years. Section 2 identifies what was left unresolved during the 1972 normalization between China and Japan. Section 3 discusses attempts on cooperation over institutionalization in the bilateral relations. Section 4 will elucidate the impact of the 2012 anti-Japanese protests in China for the future course of Sino-Japanese relations. Finally, Section 5 surveys the prospect of Sino-Japanese relations by suggesting a three-pronged emergency proposal.

\footnotetext{
${ }^{1}$ Kazuko Mori, Nicchu kankei: Sengo kara shinjidai e [Sino-Japanese Relations: From PostWWII to a New Era] (Tokyo: Iwanami Shoten, 2006) (Chinese edition, Beijing: Leterature of Social Sciences Publishing House, 2009).
} 


\section{Forty Years of Transformation: A Period-by-Period Classification}

The Sino-American rapprochement in 1971 led to a thaw in Sino-Japanese relations. After five days of negotiations, Sino-Japanese diplomatic relations were normalized on September 29, 1972. For the next 40 years, the relationship went through many twists and turns. Unfortunately, not only has the relationship failed to improve, with new issues emerging without the old ones being resolved, and with the addition of new actors such as the citizenry and public opinion, there has also been an increase in the likelihod of conflict, mistrust, and destabilization. This 40-year period is divided and discussed into four parts.

\section{(1) The 1970s: A Period of Strategic Friendship}

Normalization brought China-mania in Japan. This was because the citizenry, the financial sector and the political sector (excluding those aligned with Taiwan) had in fact been anticipating diplomatic normalization with China since the 1960s. Still, it was too much to hope for enthusiasm for Japan in China, where the embers of the Cultural Revolution still smoldered. Nixon and Kissinger's rapprochement with China was purely strategic. Aiming towards an "honorable withdrawal" from Vietnam and a turn for the better in the strategic balance with the Soviet Union, the process resulted in the Sino-Japanese diplomatic normalization also having strong strategic qualities. In particular, China was thinking about strategically resisting its primary enemy, the Soviet Union, and hastened the improvement of Sino-Japanese diplomatic relations. Beijing was also hurried by the fact that Mao Zedong and Zhou Enlai were in advanced age. Although it took seven more years for the Treaty of Peace and Friendship between Japan and the PRC to be concluded due to circumstances in both countries, Sino-Japanese relations in the 1970 s could be basically conceived as amicable.

(2) The 1980s to the mid-1990s: A Period of Coordination and Development For Beijing, after deciding on advocating policy of modernization at the Third Plenary Session of the $11^{\text {th }}$ CPC Central Committee in 1978, the launch of Ohira administration in Japan which was enthusiastic about articulating cooperative relations with China, was fortunate. In addition, the booming international economy of the 1980 s provided tailwind to Chinese modernization. For the fifteen years of this period, as the US and Japan favored a "strong and stable China", the Sino-Japanese relations had been able to maintain a stable status despite repeated friction over the historical problem, such as the textbook revisions. Prof. Ezra Vogel considered the 1980 s to be the decade of the "Golden Triangle" between the 
US, China and Japan. ${ }^{2}$

The epitome of the favorable bilateral relations was the provision of government loan to China starting from 1980. Table 1 indicates the share by country of government loan that China received from the 1980s. As the data shows, Japan's dominant role is evident. China also accepted the bilateral structure of "a country giving support and a country receiving support."

\begin{tabular}{c|c|c|c|c}
\hline Rank & Country & $\mathbf{1 0 0}$ Millions of US dollars & Item Count & $\begin{array}{c}\text { Percent of } \\
\text { Total \% }\end{array}$ \\
\hline 1 & Japan & 97.27 & 72 & 41.91 \\
\hline 2 & Germany & 22.89 & 42 & 9.86 \\
\hline 3 & France & 19.56 & 80 & 8.42 \\
\hline 4 & Spain & 18.32 & 107 & 7.89 \\
\hline 5 & Italy & 16.21 & 47 & 6.98 \\
\hline & Total & 223.8 & 1351 & 100 \\
\hline
\end{tabular}

Table 1: Japan's Share of Foreign Government Loan received by China (Cumulative values 1979-1999, Top Five)

Source: Xiaoguang Lin, Riben zhengfu kaifa yuanzhu yu zhongri guanxi [Japan's ODA and Sino-Japanese Relations] (Beijing: World Knowledge Publishing House 2003), p.381. For an evaluation of Japan's aid contribution to China's external liberalization see Zhaokui Feng, "Zhongguo de gaigekaifang yu ribenyinsu" [China's Reform and the Japan Factor], World Economics and Politics 10 (2008), pp. 7-15. Feng points to the fact that Japan's aid helped China to: (1) Resolve severe capital shortfall (40\% of basic construction costs in the 1980s);

(2) stimulate expansion in China's trade and FDI; (3) provided technological assistance, and

(4) promoted environmental protection.

(3) The Mid-1990s to 2004: A Period of Structural Change

1995 marked the fifty-year anniversary of the end of the Sino-Japanese War. From this year onward, the structure of the Sino-Japanese relations changed significantly in several dimensions.

The first epochal change was the end of the Cold War and thus the conclusion of the post-war period. In particular, most Japanese people believed that "the postwar period ended." The problem was that in China, where the level of domestic opening was increasing due to economic growth and the emergence of internet, it was the first period when the Chinese people could voice their opinions about the Sino-Japanese War and the post-war settlement. In other words, in China, this is when the post-war period started. The second change came with China's economic growth and development into a powerhouse at a time when the Japanese economy entered a long period of stagnation. The structure of the relations, namely "a country giving support and a country receiving support", greatly altered. The third

2 Ezra Vogel et al., ed., The Golden Age of the U.S.-China-Japan Triangle, 1972-1989 (Harvard University Press, Cambridge, 2002). 
change was the result of tensions that arose across the Taiwan Strait due to the election of the first Taiwanese President Lee Teng-hui who supported Taiwan's independence. In response to China's missile tests, the US sent two aircraft carriers to the Taiwan Strait. As a result, public opinion in Japan came to distrust and dislike China.

It was in 1995-1996 that the controversial debate regarding the renunciation of war clause in the Japanese constitution started to tilt towards a revision. This epitomized the "end of the post-war period" in Japan. ${ }^{3}$

(4) From 2005 to Today: A Period of Anxiety and Distrust

The most recent period began with the anti-Japanese demonstrations that occurred in the urban areas of China in the spring of 2005. The trigger of these events was the annual visit to Yasukuni Shrine by Japanese Prime Minister Koizumi starting from 2001, despite China's furious criticism. The anti-Japanese demonstrations outbroke due to an old issue, but new issues have also been surfacing. As seen in the "poisoned dumpling incident" in 2008, safety problems on the level of dayto-day life have also surfaced. Additionally, conflicts relating to interests, such as the territories of the Senkaku Islands and the East China Sea, and the conflict regarding rare earth metals have come to the fore.

What is common to these controversies is the fact that public opinion, including their voice on the internet, has a large influence on the bilateral relations (much of the public opinion is extremely emotional). The governmental and diplomatic authorities have also demonstrated a decreasing capability on controlling the situation. In China, opening-up and marketization have caused the pluralization of interests. Major companies involved in arms production and natural resource have started meddling in diplomacy. In Japan, political instability caused the loss of controlling ability and the absence of diplomacy. Figures 1 and 2 below show the change of mutual image of both countries. Although there is data indicating that at least $80 \%$ of Japanese people do not feel affinity towards China, there is notable data from the first half of 2012 (before the demonstrations regarding the Senkaku Islands) indicating that at least half of university students in Beijing considered Japan to be "normal." It is also telling that unlike in 2005, the major force behind demonstrations in 2012 was not the university students.

\footnotetext{
${ }^{3}$ For detailed data on Japan's changing view of constitution, see Iokibe, Makoto, ed., Sengo nihon gaikoshi [Post-war Japanese Diplomatic History] (Tokyo: Yuhikaku 2006), p. 108.
} 


\begin{tabular}{c|c}
\hline Highly friendly & $2.30 \%$ \\
\hline Friendly & 10.6 \\
\hline General & 53.2 \\
\hline Unfriendly & 21.8 \\
\hline Very unfriendly & 10.4 \\
\hline Unclear, no response & 1.7
\end{tabular}

Figure 1: The View of Japan by Chinese University Students in Beijing

Source: An April/May 2012 survey of 10 universities collecting 2029 responses (92.2\% response rate) in: Xingyu Wang, "Zhongguo daxuesheng duiri renzhi de wen juan diaozha" [The poll data on the view of Japan by Chinese university students] Riben Xuekan [Japanese Studies] (Issue 5, 2012), pp. 125- 140.

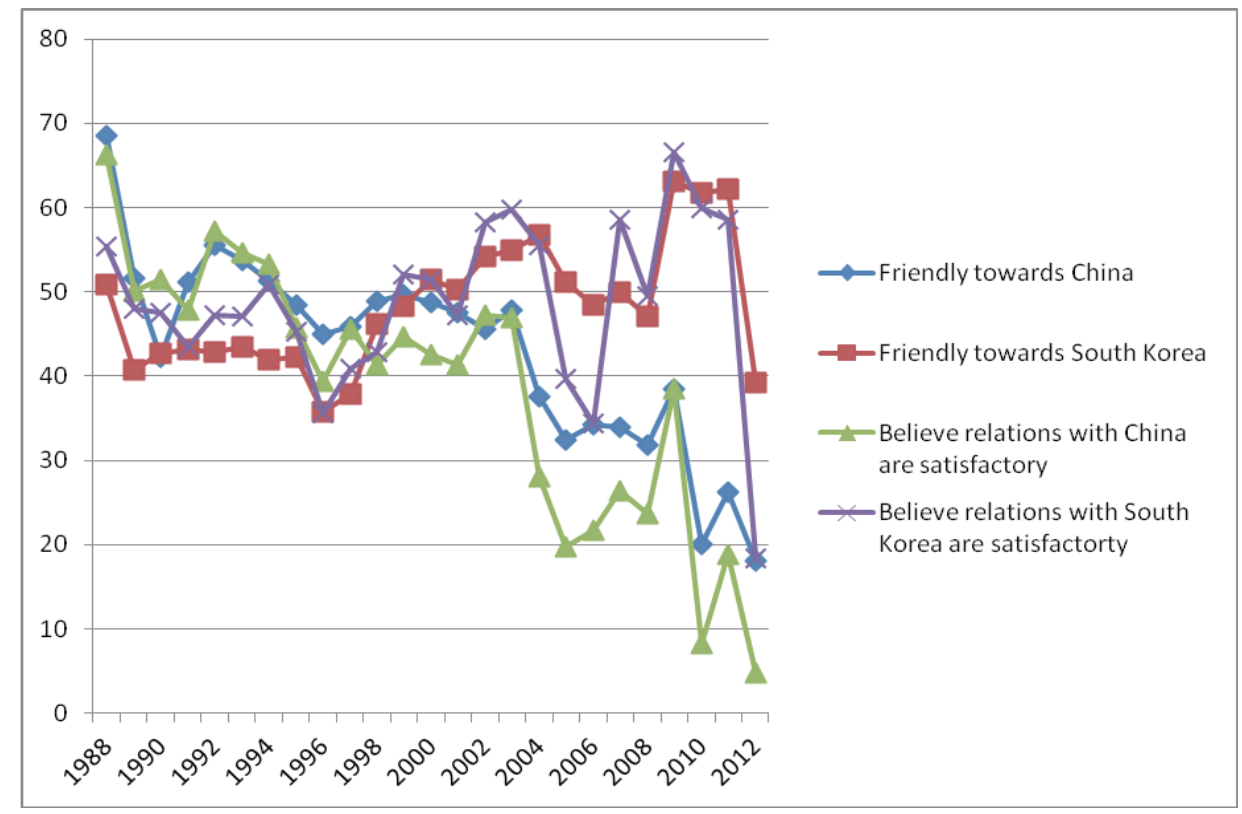

Figure 2: Japanese View on Diplomatic Relations with China and South Korea Source: Government of Japan, Cabinet Office, Public Opinion Polls on Diplomacy. Survey conducted during October-December of each year, randomly selecting 1800 people. Only the 2011 poll was conducted in January 2012, at < http://www8.cao.go.jp/survey/h24/h24-gaiko/ index.html > (searched date: November 24, 2012).

\section{A Re-examination of the 1972 Normalization: What was Left Unresolved}

\section{What was Left Unresolved during the 1972 Normalization: the Source of Suspicion}

Forty years has passed. The time has come to review the 1972 normalization itself 
from a long-term perspective. The author came to think this way after reading Hattori Ryuji's Sino-Japanese Diplomatic Normalization. ${ }^{4}$ Another reason for rethinking the conventional understanding is the large-scale, violent anti-Japanese demonstrations over the Senkaku Islands in September 2012.

Hattori Ryuji's Sino-Japanese Diplomatic Normalization has two major points. First, it points out an important fact that despite the three principles for restoring Sino-Japanese diplomatic relations, which the Chinese side firmly stuck to (namely, the People's Republic of China is the sole legitimate government of China; Taiwan is an inalienable part of the territory of China, and the 1952 Treaty of Taipei is unlawful and should be annulled), the treaty negotiations concluded with Japan in an advantageous position with respect to the second and third principle. Ultimately, Japan succeeded in only going so far as to state that it "fully understands and respects" China's position that Taiwan is part of China, and that Japan "firmly maintains its stand under Article 8 of the Potsdam Proclamation." In addition, Japan succeeded in removing the reference to the Treaty of Taipei from the Joint Communiqué, instead handling this with a unilateral explanation by Foreign Minister Ohira that "the Treaty of Taipei has been terminated."

Second, the book demonstrates the success of diplomatic normalization was highly dependent on the partnership between political leaders and the bureaucracy, primarily in the Ministry of Foreign Affairs (MOFA), and the efforts of the primary parties who engaged in the normalization negotiations. Hattori emphasizes that in the 1972 negotiations, China conceded quite a bit, and that it was actually Mao Zedong and Zhou Enlai who were zealous and hurried for normalization. In other words, Hattori's basic view is that Japan gained more in the 1972 negotiations and conceded little, and thus was successful.

Nevertheless, the author is not satisfied in the following three points. First, Hattori's evaluation is too narrow. He argues that Japanese ulterior motives had run through the 1972 diplomatic negotiations and Japanese diplomatic success was a question of negotiation tactics, and "how much this is understood in today's China is a separate issue." The official understanding in China is that Japan had recognized China's three principles for restoring diplomatic relations. The 1972 negotiations should be strictly reexamined not as a diplomatic game but as a historical settlement for both two countries as a new start.

Second, as Hattori also notes, there is the problem of "the hearts of the Chinese people, who were subjected to unprecedented wartime damage, and who were sidelined by the diplomatic normalization." To be sure, many Japanese people considered it a "success" that there was no claim for compensation during the

\footnotetext{
${ }^{4}$ Ryuji Hattori, Nicchu kokko seijoka [Sino-Japanese Diplomatic Normalization] (Tokyo: Chuko Shinsho, 2011).
} 
1972 negotiations. In 2005, the "Chinese people who were abandoned" once again turned their strong criticism towards Mao Zedong and Zhou Enlai's fundamental principle with respect to Japan (the "binary theory" of differentiating Japanese militarists from the ordinary Japanese people). As a consequence, the 1972 negotiations was not a sufficient settlement of the previous war, and suspicion and distrust toward Japan remained among the Chinese people.

Third, there is one more issue that was left unresolved. What the Japanese side struggled with the most during the 1972 negotiations was how to achieve consistency between the negotiations and the "fictitious policy towards China." That is, diplomatically treating mainland China as if it did not exist while considering relations with Taiwan as the totality of relations with China as it had been diplomatic practice since the 1950s. In other words, the conundrum was how to defend the "fictitious policy towards China." Was Japan's decision in the 1950s the correct one? How should the policy towards China and towards the US be? The 1972 negotiations did not handle these questions, and the crucial issue was left untouched.

The unresolved problems mentioned above were not discussed afterwards. As a result, the suspicion and distrust in China has never been cleared out, and instead significantly accumulated. This bounced back to Japanese, leading to an increase of anti-China sentiment in the Japanese society. In this way, 40 years has passed.

\section{Old and New Issues between Japan and China}

Disputes over maritime resources and territory, such as the Senkaku Islands, are new issues following the 1970s when China (and Taiwan) officially began to assert their territorial rights. What other problems are there between Japan and China?

The disputes and issues have emerged between the two countries since 1972 are, in a simplified manner, as depicted in Figure 3. The first layer is the problems of historical understanding. It is the basic layer that can be classified as issues of values that emerge due to the continuation of problems before 1972 . These problems have continued to smolder and erupted occasionally. They are troublesome problems that reside in the layers of history between the two countries.

The second layer related to power. They are disputes and conflicts regarding strategy, power, and regional leadership such as the US-Japanese alliance, the Taiwan problem, and the issue of Japan's seeking for a permanent seat in the UN Security Council. These can be considered issues that have emerged since 1972. However, in the case of Taiwan, regional leadership, the root of these issues goes back to pre-1972 history. Therefore, problems of the first layer are often intertwined with those of the second. 
The third layer consists of disputes relating to specific interests, such as natural resources as well as land and maritime territory. It appears that since 2010, history problems between China and Japan have receded and conflicts over power and interests, and territorial disputes have become prevalent.

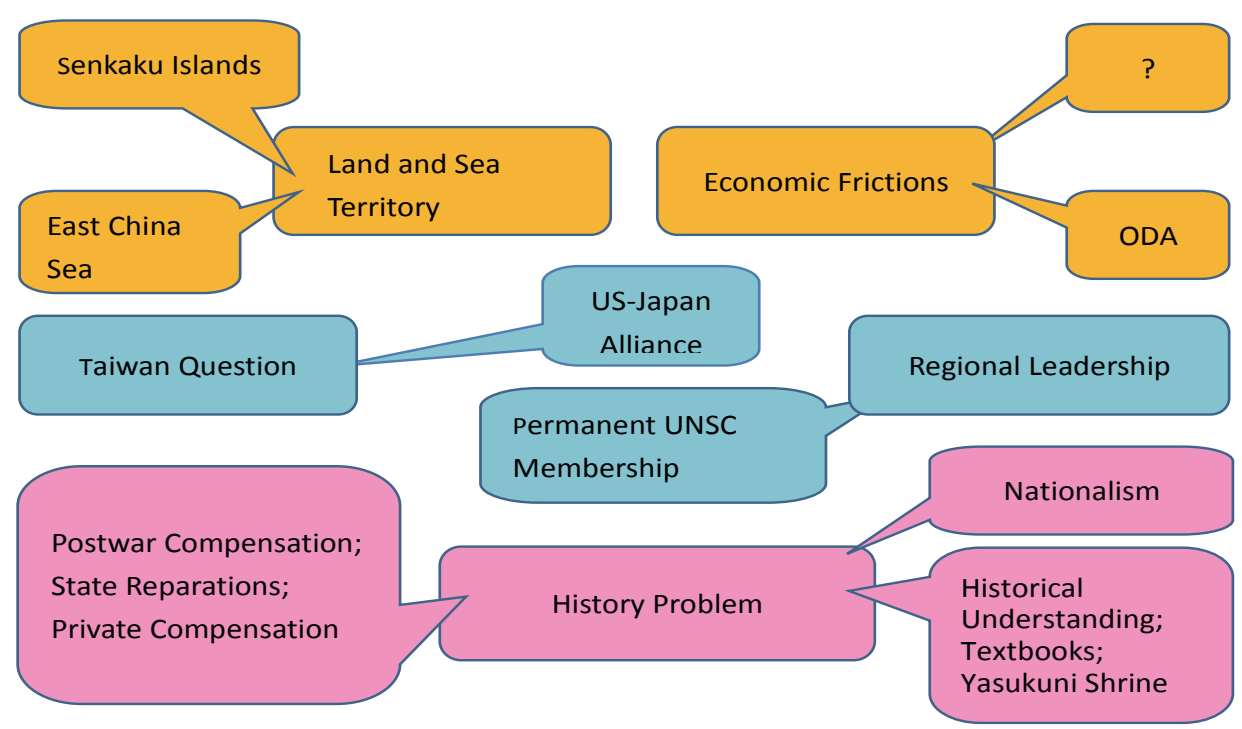

Figure 3: Issues between Japan and China; A Three-layer Structure of Values, Power and Interests

Source: By author

The unique structure of the Sino-Japanese relations means that conflicts over power (the second layer) and conflicts over interests (the third layer) often become entangled with the conflicts in the first layer. In fact, it is a character of the SinoJapanese relations that it is not possible to use reason to handle the kind of disputes over the reasoning of power and interests that exist in any other bilateral relations. The crucial point is that what is behind those disputes. Mutual distrust and suspicions lay in the foundation of Sino-Japanese relations, aggravating the conflicts at the third and second levels and causing unnecessarily disputes to be escalated. Why can the strong suspicion and distrust at the foundation not be eliminated, and why are they continuously amplified?

\section{Attempts at Institutionalizing the Sino-Japanese Relations - The Fourth Period}

\section{The Start of Institutionalization: Five Channels}

The bilateral relations in the $21^{\text {st }}$ century (the fourth period) faced a period of 
structural crisis. After a drastic change in the strategic environment in the East Asian region, the rise of China and the political instability in Japan, the trust between Japan and China crumbled fundamentally due to Japanese Prime Minister Koizumi's visits of Yasukuni Shrine. Since the inauguration of the Abe cabinet in October 2006, mutual visits by Japanese and Chinese leaders were made at least once per year and the relations began to recover.

Meanwhile, mechanisms for dialogue and consultation were launched at a variety of levels. Up until this point, the Sino-Japanese relations were extremely informal and had an intrinsic fragility. Thus, the attempt at "institutionalization" can be viewed as a major transformation. Five primary mechanisms for dialogue and cooperation between China and Japan are discussed as follows:

\section{(1) Comprehensive Policy Dialogue (Japan-China Strategic Dialogue)}

Through diplomatic channels immediately before the anti-Japanese demonstrations in February 2005, the Chinese side proposed holding talks on Taiwan and North Korea over the issue on the establishment of a security arrangement in East Asia. China also initiated a similar strategic dialogue with the US in 2004, which was launched in August 2005. Furthermore, in December 2006, the US-China Strategic and Economic Dialogue and the High-Level Economic Dialogue at the ministerial level between Japan and China were set up.

The Japan-China Strategic Dialogue (initially called the Comprehensive Policy Dialogue in Japan) started at the end of the Koizumi administration in May 2005 and continued through meetings in June 2005, October 2005, February 2006, June 2006, September 2006, January 2007, February 2008, June 2009, February 2011, and most recently the eleventh meeting between the Vice-Ministers for Foreign Affairs Sasae Kenichiro and Zhang Zhijun in June 2012.

The first major country to which China proposed a strategic relationship was Russia in 1996."Strategic" does not presuppose matching interests, but has the triple connotation of being long-term, full-scale and global. It is likely that China's call for "strategic dialogue" with Japan was a manifestation of an intention to propel the Sino-Japanese relationship to the same framework as the relationship with other major powers such as the US and Russia. Incidentally, when the USChina Strategic Dialogue began, a Chinese debater argued that the purpose of the strategic dialogue was to "eliminate mistaken strategic decisions to certain degree." 5

(2) High-Level Economic Dialogue

\footnotetext{
${ }^{5}$ Zhongying Pang, "Xinlang jiu zhongmei zhanlue duihua-lianxianguojiwentizhuanjia," [Sinanet interviewed international relations specialists on the issue of Sino-American strategic dialogue] Sina Net (August 1, 2005), at < http://news.sina.com.cn/c/2005-08-01/20557383048. shtml $>$ (searched date: November 11, 2012).
} 
The High-Level Economic Dialogue began in December 2007, spurred by Chinese Premier Wen Jiabao's visit to Japan in April of the same year. It developed out of the Japan-China Economic Partnership Consultation that had been operating since 2002. The four themes are macroeconomic adjustment, cooperation in environmental protection, cooperation in trade and investment, and regional/international economic problems. The attendees on the Japanese side include the Minister for Foreign Affairs, the Minister of Finance, the Minister of Economy, Trade and Industry, the Minister of State for Economic and Fiscal Policy, the Minister of the Environment, and the Minister of Agriculture, Forestry, and Fisheries. On the Chinese side, the Minister of Foreign Affairs, the Chairman of the National Development and Reform Commission, the Minister of Finance, the Minister of Agriculture, a Vice Minister of Commerce, and the head of the Ministry of Environmental Protection participate in the meetings. This is literally a high-level ministerial consultation regarding the economy.

However, while the economic strategic dialogue between the US and China that started a year earlier is progressing well, the dialogue between Japan and China has not gone smoothly. Particularly, problems emerged since the Democratic Party of Japan (DPJ) took the power. The controversy over the Chinese restrictions of rare earth element exports in September 2010 is the most prominent example.

\section{(3) Talks Regarding Problems in the East China Sea}

This mechanism for dialogue at the level of the Asian Affairs Bureau of the Ministry of Foreign Affairs aims at the demarcation of boundaries in the East China Sea, the exchange of opinions on joint development, and the peaceful resolution of problems in the East China Sea. It began in October 2004 and had been convened 12 times by June 2008 .

There was an "important development" at the $12^{\text {th }}$ meeting in 2008, when a basic consensus for joint development of the East China Sea gas field by Japan and China was reached. However, the relationship deteriorated with the Japanese seizure of a Chinese fishing trawler near the Senkaku Islands in September 2010, which resulted in furious Chinese protests. During Japanese Prime Minister Noda's visit to China in the end of 2011, Japan and China agreed to create a security mechanism to prevent maritime conflict, including the installation of a military hotline. Japan-China talks on maritime affairs began in May 2012 (in Hangzhou). It is expected that talks about the East China Sea will expand and come to be held regularly. ${ }^{6}$

\footnotetext{
6 "Jiedu zhongri haiyang anbao cuoshang cheng diaoyudao cheng hexin wenti," [Interpreting China-Japan maritime security talk: Diaoyudao problem became core issue ] People's Daily Online (May 15, 2012) at < http://www.chinanews.com/gj/2012/05-15/3889318.shtml> (searched date: November 15, 2012).
} 
(4) Defense Vice-Ministerial Level Talks

The Japan-China defense dialogue began with vice-ministerial level talks in 1997. These meetings and mutual visits by high-level defense officials (the head of the Japan Defense Agency, later became the Ministry of Defense) are the two channels that continue to the present day. By July 2011, the vice-ministerial talks had been held nine times.

According to the information that has been passed along, the vice-ministerial talks are a formality where every time the Japanese side asks for greater transparency of China's military strength and strategy, and the Chinese side consistently makes requests to Japan with respect to the status of Taiwan.

\section{(5) Joint History Research Committee}

The problem of historical understanding between Japan and China came to the fore and dominated bilateral relations during the Koizumi era. After Japanese Prime Minister Abe's visit to an APEC conference in China in October 2006, an agreement was reached between the foreign ministers of Japan and of China, Aso Taro and Li Zhaoxing, respectively, to "implement a Japan-China Joint History Research Committee based on the spirit of looking squarely at history and facing the future." This resulted in "joint research regarding the 2000-year history of exchanges, the unfortunate history of the modern period up to 1945, and the history of the development of relations after WWII." The committee was launched in December 2006 with the Japan Institute of International Affairs as the contact on the Japanese side and the Institute of Modern History at the Chinese Academy of Social Sciences (CASS) as the contact on the Chinese side. The Japanese chairman is Kitaoka Shinichi, Professor at the University of Tokyo and the Chinese chairman is Bu Ping, Director of the Institute of Modern History at CASS. The first meeting was held in December 2006, the second in March 2007, and the third in January 2008. At the fourth meeting in December 2009, both sides released a report, ending the first stage. The report went no further than to state the historical understanding of each side, and there is no plan for when to start the second stage. Thus, this channel for intergovernmental discussion regarding the history problem is at a very fragile state compared with that between Japan and South Korea.

Looking at the Sino-Japanese channels for intergovernmental communication, which could barely be maintained, it appears that the Chinese side is motivated towards institution-building and, aside from joint research on the history problem, is using the relationship with the US as a model. However, on the one hand China's attempts at institutionalizing its relationship with Japan and bringing it up to a strategic level have been at the mercy of public opinion voiced on the 
internet. This became particularly apparent with regard to territorial issues. On the other hand, since the start of the DPJ administration in 2008, there has been none of the initiative that we should see in Japan's China policy. There is simply an absence of diplomacy. Amidst such circumstances, both countries have fallen into a vicious cycle in which conflicts over land, sea territory and resources incite stormy nationalism, stirring up unease, distrust, and suspicions at the citizen level in both countries.

\section{The Vagueness of the "Mutually Beneficial Relationship based on Common Strategic Interests"}

Starting from 2006, faint glimmers of possible progress in institutionalizing SinoJapanese relations became visible. However, with the political instability and absence of diplomacy since 2008, and the fishing trawler collision incident near the coast of the Senkaku Islands in September 2010 as well as the August 2012 controversy over the purchase of some of the islands by the Japanese government, the extreme thinness and fragility of the newly-formed Sino-Japanese channels and institutions was exposed.There is no consensus between the two countries about important issues such as the actual meaning and content of the "mutually beneficial relationship based on common strategic interests," which was mutually agreed upon during the Abe and Fukuda administrations.

The first time the Sino-Japanese relationship was characterized as a "mutually beneficial relationship based on common strategic interests" was in a joint press released on "Building a Mutually Beneficial Relationship based on Common Strategic Interests" when Japanese Prime Minister Abe visited China in October 2006. During Chinese Premier Wen Jiabao's visit to Japan in April of the following year, Wen stated that he considered the "spirit" of the mutually beneficial relationship based on common strategic interests to be "contributions and responsibility for peace and stability in Asia and the world, cooperation at the bilateral, multilateral, and international levels, and an expansion of shared interests," and noted the following five points as specific components:

(1) Building a politically trusting relationship through leader visits, greater political transparency, and organizational exchanges.

(2) Cooperating for mutual benefit in areas including resources, environment, finance, communication and intellectual property.

(3) Maintaining regional stability through dialogue and exchanges with respect to defense issues.

(4) Engaging in human and cultural exchanges among youths, the media, cities, and the citizenry. 
(5) Cooperating with regard to regional and global problems such as the North Korean nuclear problem, UN Security Council reform, ASEAN-style "open, transparent, and inclusive" cooperation in the East Asian region.

Strategic dialogue is required for the very reason that relationships are unstable and involve sensitive issues. Japan, however, has been extremely vague in response to China's clear resolve that it is necessary to create a mutually beneficial relationship based on common strategic interests. According to Prime Minister Fukuda when he visited China, a "mutually beneficial relationship based on common strategic interests" would have the following three pillars.

(1) Mutually beneficial cooperation, especially in the field of the environment and energy conservation, and in intellectual property protection.

(2) International contribution in the fight against terrorism, the abduction problem and denuclearization in North Korea, UN Security Council reform, and assisting the poor in Africa.

(3) Mutual understanding and trust, through increasing dialogue, understanding, and trust in the areas of youth exchanges, intellectual exchanges, and security. ${ }^{7}$

On the Chinese side as well, dissatisfaction exists over the "strategic dialogue" with Japan. According to one view, "to begin with, strategic dialogue is attempting to deal with both a bilateral relationship from a sophisticated strategic perspective, and international problems that both parties have an interest in," and dialogue centered on the future and crisis management is proceeding between the US and China as "responsible powers." The strategic dialogue with Japan, however, is entangled by the future and the history problem. As a consequence, the precise "placement" is difficult to be positioned, and most of the dialogue is about the history problem and the bilateral relationship. ${ }^{8}$

To make the Sino-Japanese "mutually beneficial relationship based on common strategic interests" to being truly "strategic," it is necessary for Japanese diplomacy to have a regional and global strategy, and for both sides to have a relationship in which they frankly assert their strategy and interests in the world and the region.

\footnotetext{
${ }^{7}$ Speech given by Japanese Prime Minister Fukuda at Peking University on December 28, 2007.

${ }^{8}$ Wang Yiwei, "Zhongriyu zhongmei zhanlue duihua de yitong," [The similarities and differences between Sino-American and Sino-Japanese strategic dialogue] People's Net (February 17, 2006) at < http://japan.people.com.cn/GB/35464/35488/4115812.html > (searched date: November 15, 2012).
} 


\section{Addendum: The 2012 Anti-Japanese Riots}

\section{What Happened?}

Since 2006, the institutionalization of the relationship has been attempted bit by bit and in June 2008 the two countries managed to agree on joint resource development in the East China Sea. The relations, however, became instantly tensed when in September 2010 a Chinese fishing vessel entered the maritime area of the Senkaku Islands and was seized and its crew detained by a Japanese Coast Guard patrol boat. The DPJ administration in Japan did not follow to precedent and responded the issue by arresting the crew according to Japanese law. Due to this reason, China, which follows the basic principle of "not changing the status quo," was strongly provoked.

The trigger for the anti-Japanese riots in September 2012 was provoked by Tokyo Governor Ishihara Shintaro's announcement in Washington on April 16 that the city of Tokyo would purchase the Senkaku Islands from its owner, a private person who had been leasing the islands to the national government. Japanese Prime Minister Noda Yoshihiko, who was concerned about the risks of this move, informed the city of Tokyo of a plan to nationalize the islands and started negotiations with the owner. Anti-Japanese demonstrations reacting to the nationalization of the islands enlarged starting on August 19. On August 27, there was an incident in which the Japanese flag was ripped off from the official vehicle of Japanese ambassador to China Niwa Uichiro while it was driving.

On September 3, the Japanese government entered into a contract to purchase the Senkaku islands for 2.05 billion yen and nationalize them. On September 11, the nationalization was officially approved at a cabinet meeting and the transfer was completed.

Completely ignoring the strong statement by Chinese President $\mathrm{Hu}$ Jintao to firmly oppose Japan's nationalization of the islands (at the APEC meeting in Vladivostok on September 9), the strong backlash from China was said to be due to the Japanese government making the official decision to nationalize just two days later. This is because President $\mathrm{Hu}$ had completely lost face.

The anti-Japanese demonstrations became large-scale, violent, and from September 11 spread across the entire country. On September 15, numerous Japanese-owned businesses and supermarkets were looted and damaged. In Hunan province, almost all of the first to fourth floors of the supermarket Heiwado were destroyed. On September 18 (the anniversary of the Mukden incident that started Japan's invasion of Manchuria in 1931), the authorities finally brought the demonstrations under control.

The direct trigger for the clash was the "nationalization." However, the 
view of the Japanese government, media, and most of the citizenry is that the government's action was due to the concern that if Tokyo purchased the islands, Governor Ishihara, who is an anti-China nationalist, would further provoke China by constructing a lighthouse and harbor on the island.

In October, cabinet member Maehara Seiji of the Noda administration revealed the following facts in a television address: On August 19, Governor Ishihara and Prime Minister Noda had a secret meeting. The prime minister heard from the Governor his hardline stance to purchase the islands and not to hesitate from starting war with China, and so became gravely concerned that "without nationalization, terrible things will happen."

Although the demonstrations have calmed down, a fierce exchange of criticism is continuing. As if in an attempt by the Chinese government to involve international society, Chinese Foreign Minister Yang Jiechi announced seven times at the UN General Assembly in September that Japan stole the Senkaku Islands during the First Sino-Japanese war, and strongly criticized Japan as engaging in money laundering, using "robber's logic". This contrasts with the speech by Prime Minister Noda, who stated without pointing fingers that the situation would "be resolved according to international law." China also did not send the governor of the People's Bank of China or the head of the Ministry of Finance to the IMFWorld Bank annual meeting held in Tokyo in mid-October. In a rare move, Japan's ambassador to the US and the Japanese foreign minister submitted contributions to the mass media in the US and France, and started to explain the situation to each country.

As discussed later, on the one hand, China's criticism of Japan is very fundamental. On the other hand, the Japanese side also fundamentally rejects Chinese claims, saying "there is no territorial dispute between the two countries." As a result, no starting point for moderation and negotiation can be found.

\section{Japan's Official Line}

Both sides assert territorial possession of the Senkaku Islands, but let us briefly summarize Japan's assertions that are:

1) Using logic employed through the inclusion of Okinawa prefecture (Japanese territory since 1884) since 1885 , Japan repeatedly performed detailed surveys of the Senkaku Islands, and officially incorporated the territory into Japan by cabinet decision in January 1895.

\footnotetext{
9 "Japanese high official said Prime Minister Noda revealed the aim to buy the Islands" Huanqiu shibao [Global Times], at $<$ http://world.huanqiu.com/exclusive/2012-10/3184891. html $>$ (searched date: November 24, 2012).
} 
2) The Senkaku Islands are not part of Taiwan or the Pescadores Islands, which were ceded to Japan in the Treaty of Shimonoseki during the post-war settlement of the First Sino-Japanese War, which came into effect in May 1895.

3) The islands are not included in the territory renounced by Japan in the Treaty of San Francisco, which ended World War II. They were placed under US administration in accordance with Article III of this treaty, and were officially placed under Japanese administration in June 1971 in accordance with the Agreement between Japan and the United States Concerning the Ryukyu Islands and the Daito Islands. Japan has had effective control ever since.

4) China has not consistently been demanding the territory of the Senkaku Islands. It was after the UN Economic Commission for Asia and the Far East (ECAFE) investigation revealed petroleum resources in this maritime region (in 1968) that China and Taiwan starting to make an issue over territorial rights in the latter half of 1970.

5) There is no territorial issue between Japan and China.

6) Although the intentions of the Chinese side have been heard in 1972 and 1978 that the Senkaku issue would not be debated (the words of Zhou Enlai in 1972), or would be shelved or jointly developed (Chairman Deng Xiaoping in 1978 at a press conference), there is no territorial issue between Japan and China. ${ }^{10}$

Although there are some inside MOFA and several politicians who recognize the existence of a territorial issue and are of the opinion that the issue of territorial rights should be set aside for repairing the relationship, they are only a few who feel this way.

In my view, there are two problems for the Japanese side. The first is that as long as Japan cannot depart from the position that "there is no territorial issue between Japan and China," it is not possible to make an explanation to China, much less to negotiate with China, and even less to debate "shelving" or "joint development." Japan has fallen into self-contradiction.

The other is that leadership is ebbing under the chaos of the politics, and diplomatic ability has dropped a notch. Much was lost due to the slapdash decision of "nationalizing" the islands.

\footnotetext{
10 The official statements of Japanese government over the Senkaku Islands issue can be checked from the website of Japanese Ministry of Foreign Affairs (MOFA) : http://www. mofa.go.jp/mofaj/area/senkaku/kenkai.html (Searched Date: November 15, 2012)
} 


\section{China's Official Line}

As mentioned previously, it was in the latter half of 1970 that the People's Republic of China and the "Republic of China," Taiwan, officially asserted territorial rights over the Diaoyu Islands. From 1895 to 1970, China did not once assert territorial rights over the Senkaku Islands and did not protest Japanese sovereignty.It is well known that in January 8, 1953, the People's Daily published an editorial titled "Support the Battle of the Ryukyuan People against the US" that considered the Senkaku Islands to be part of the Ryukyu Islands.

But thereafter, the Senkaku Islands were legally incorporated into Chinese territory for the first time in the Law of the Territorial Sea in February 1992, saying, "The land territory of the People's Republic of China includes the mainland of the People's Republic of China and its offshore islands, Taiwan and all islands appertaining thereto including the Diaoyu Islands; the Penghu Islands; the Dongsha Islands; the Xisha Islands; the Zhongsha Islands and the Nansha Islands, as well as all the other islands that belong to the People's Republic of China."

When Japan's plan to nationalize became public in the summer of 2012, China made clear a hardline stance against Japan. In the white paper on the Diaoyu Islands issued on September 25, 2012, China's firm and fundamental assertions are particularly clear:

1) China was the earliest to discover and name the Diaoyu Islands, in the $14^{\text {th }}$ century. They were under Chinese jurisdiction for a lengthy period, were marked as Chinese territory in maps starting in 1579 , and are territory belonging to China.

2) Japan took advantage of the First Sino-Japanese War in 1895, and "stole" the Diaoyu Islands along with Taiwan and the Penghu Islands.

3) The Cairo Declaration in 1943 indicated the return to China of the "territories Japan has stolen from the Chinese," but Japan violated this and has not returned the Diaoyu Islands as they should have been.

4) The handling of the Senkaku Islands by the US and Japan respectively during the US-Japan negotiations and the Okinawa negotiations in 1951 and 1971 was illegal and invalid.

5) Japan's assertion is totally unfounded, and is "a challenge to the postwar international order established by such legal documents as the Cairo Declaration and the Potsdam Proclamation, and seriously violates the obligations Japan should undertake according to international law."

6) At the time of normalization of relations and the Treaty of Peace of Friendship, the leaders of both countries reached the understanding of "leaving the issue of the Diaoyu Islands to be resolved later." The 
"nationalization," which violated this, was a severe infringement on Chinese sovereignty, undermined the Sino-Japanese relationship, and "rejected and challenged the achievements of the victory of the World Anti-Fascist War."

Why did China, which did not assert territorial rights for a long time until 1970 make such strong and fundamental assertions in this white paper? Two reasons can be considered.The first is the view of international politics since the 1990s that holds national interests to be absolute. National interests began to be squarely affirmed in China immediately after the Tiananmen Square incident. The book entitled An Analysis of China's National Interest published in 1996 by Yan Xuetong, a well-known professor of Tsinghua University, was shocking. His arguments are as follows: (1) There is no class-conscious characteristics to national interests; (2) International interests and national interests can coexist; (3) National interests change and develop; (4) Public economic interests expand with the growth in economic activity. ${ }^{12}$

To elaborate on this through the logic of realism, the more China's economy expands and spreads throughout the world, the more national interests that must be guarded expand. The precedents of this thinking have already been set at the end of the $19^{\text {th }}$ century when a subset of politicians in Japan asserted a lifeline theory and a profit line theory, and the military subsequently expanded military activities to protect the lifeline and the profit lines. In other words, Yan's argument is essentially a $19^{\text {th }}$ century type theory of sovereignty and theory of profit reminiscent of Japanese militarism and German fascism.

China, which has risen to be an economic powerhouse in the $2000 \mathrm{~s}$, has been expanding its "national interests that must be guarded". In the white paper on "China's Peaceful Development" from 2011, state sovereignty, national security, territorial integrity, national reunification, China's political system, and sustainable development are set as six "core interests." 13 Thus, China is becoming a political and economic powerhouse and the hardening of Chinese diplomacy are progressing in tandem.

The second reason for China's recent assertiveness in territorial matters is the rise of the military or conservative military personnel politically. A remarkable change can be seen in China's diplomacy since the end of the 1990s. The influence of the foreign ministry has waned and in its place many "new participants" such

\footnotetext{
${ }^{11}$ State Council of People's Republic of China, White Paper: Diaoyudao shi zhongguo de guyoulingtu, September 25, 2012.

${ }^{12}$ Xuetong Yan, Zhongguo guojia liyi fenxi [Analysis on China's National Interests] (Tianjin: Tianjin People's Publishing House, 1996).

${ }^{13}$ State Council of the People's Republic of China, White Paper on China's Peaceful Development [Zhongguo de heeping fazhan] 2011.
} 
as government offices involved with the economy, state-owned corporations, the financial capital sector, the oil capital sector, local governments and netizens (citizens who use the internet) have emerged. In a report by the Stockholm International Peace Research Institute (SIPRI), the following characteristics of recent Chinese foreign policy decisions were noted:

1) The jurisdiction for foreign policy decisions has become more finely segmented, and the foreign ministry only constitutes one part of that.

2) The People's Liberation Army (PLA) and individual officers have started to freely appear in public debate.

3) State-owned corporations and oil capital lie behind the military personnel. In policy decisions, instead of political intervention by the military, there is a state of "segmented authoritarianism."

4) Among the new participants, the view that the national interest should be pursued more actively is dominant. ${ }^{14}$

There is a Chinese Major General named Luo Yuan who is the deputy secretary general of the Chinese Academy of Military Science. He calls himself a "rational hawk," rejects the idea that "a skilled hawk hides its talons," and in the place of "shelving" or "joint development," asserts "active conflict resolution" and "joint development with China at the lead." ${ }^{15}$ His argument about the Senkaku islands dispute is exactly the same as the white paper on the Diaoyu Islands discussed above. The white paper is founded on a hard military perspective much like his.

Two of China's problems should be noted. The first is that the leadership is weakening. The incident of Bo Xilai indicated that there are large fissures of power at the core. No matter who the new leaders will be, they will not be able to exert the kind of strong leadership seen in the past. The other problem is the prevalence of naked nationalism and populism. The recent anti-Japanese demonstrations exposed that the central government is being exposed to the destructive pressure of spontaneous nationalism, and control has become quite difficult. $^{16}$

If these two dynamics become linked, this will cause troubles because within the leadership, the only shared identity would be anti-Japanese, popular support

${ }^{14}$ Linda Jakobson, Dean Knox (Tatsumi Okabe trans.),Chugoku no atarashii taigai seisaku[New Foreign Policy Actors in China], (Tokyo: Iwanami Shoten, 2010).

${ }^{15}$ See Luo Yuan's statements in the TV show: conference on China's future strategy in the coming ten years [Weilai shinian de Zhongguo guoji zhanlüe yantaohui] at $<$ http://my.tv.sohu. $\mathrm{com} / \mathrm{u} / \mathrm{vw} / 30674077>$ (searched date: November 4, 2012).

${ }^{16}$ Yongnian Zheng, "Zhongriguanxi yu minzuzhuyi" [Sino-Japanese Relations and Nationalism], Aisixiang Net (October 2, 2012) at < http://www.aisixiang.com/data/57798.html $>$ (searched date: November 15, 2012). 
would be gained in direct proportion to the firmness of the anti-Japanese line, and anti-Japanese hardline tendencies would spread.

\section{The Characteristics of the 2012 Riots}

There were already anti-Japanese demonstrations in 2005, but once the main actor of that time, Japanese Prime Minister Junichiro Koizumi, left the stage, both countries timidly moved in the direction of a "mutually beneficial relationship based on common strategic interests." However, the appearance of anti-Japan demonstrations in China changed in 2012. The characteristics of the 2012 conflict are as follows.

First, in contrast to 2005 which was solely about the history problem, the situation of the standoff in 2012 has expanded across the board starting from concrete interests of territory and maritime regions to power struggles and the history problem. According to Figure 3, "Issues between Japan and China," this is an overall conflict including interests on the third level, power on the second level, and history/values on the first level. In particular, even after the demonstrations were brought under control, Beijing continued retaliatory diplomatic actions as it canceled most of the cultural and economic exchanges for the $40^{\text {th }}$ anniversary of diplomatic normalization between Japan and China, indicating a breakdown in the relationship even at the level of the citizenry, and this will likely leave a deep scar.

Second, this time, particularly on the Chinese side, there has been a strong tendency towards popular nationalism and populism. It is astonishing that such masses were mobilized across the entire country in a short period of time. The 2012 anti-Japanese riots indicate two facts: that the only identity for Chinese society is an anti-Japanese one, and that the more firmly anti-Japanese a leader is, the more the masses will support him or her. It can also be said that the legitimacy of Chinese rulers lies in their "anti-Japaneseness."

China's bare anti-Japanese nationalism induces a countering nationalism in Japan. The countering nationalism is linked to Japanese self-armament and strengthening of the US-Japan military alliance. It is truly a historical paradox that the very anti-Japanese actions of Chinese people condemning Japan's war crimes are driving Japanese militarization and military tension in East Asia.

Third, this incident occurred in a period of power vacuum in both China and Japan, in the gap of eroded governance. The political situation in China leading up to the $18^{\text {th }}$ National Party Congress cannot be called stable. The Bo Xilai incident in April was not caused only by a simple scandal. The roots lie in a fierce struggle for power within the leadership. At the same time, there was the standoff regarding the fundamental question of the future direction of socio-economic and political development, the one between furthering marketization or treading the path of state capitalism. In the fifth leadership generation since the revolution, the 
governing power of the Chinese Communist Party is declining and its legitimacy has been eroding. The structure of a solely anti-Japanese identity derives from this.

On the other hand, what about Japan? The new DPJ administration came to power in 2009 with high expectations of the people, but hope for political change was dashed in all manner of ways. Still, even if authority were to return to the Liberal Democratic Party, it is not expected that this would be able to save Japan from the lack of leadership, the loss of orientation and gridlock in domestic and foreign affairs, and stagnation of the economy. The lack of caution in the government's diplomacy toward China since 2010, the nationalization measure without an announcement of a basic principle regarding the Senkaku Islands issue to the citizens and to the international society in particular, the lack of leadership and the dysfunctional diplomacy have exacerbated the Japan-China conflict.

Japan and China are both facing a weakening leadership and a decline in governance. This will likely remain unchanged in the short term. The 2012 conflict may bring about a "new Cold War" that endures for a long time between the two countries.

\section{Can a "Sino-Japanese New Cold War" be Avoided?}

The impact of the anti-Japanese riots in 2012 is large. From their contents and characteristics, it is hard to see a future of warm Sino-Japanese relations. It appears that Japan and China will enter a new Cold War, which will continue for at least in the medium term. Let us consider what can be done to avoid such a new Cold War. First, there is the possibility of negotiation. In order to put the conflict over territory on the negotiating table, the following conditions are needed minimally:

1) Being able to explain that "nationalization" is not a change of the status quo regarding the Senkaku Islands.

2) The Japanese government being able to extricate itself from the fiction that "there is no territorial issue between Japan and China."

3) Being able to agree on the "tacit understanding" over shelving or joint development.

Second, let us consider what could happen if the state of the territorial issue were effectively frozen. As for China, sudden changes in foreign policy are not out of the question. China has frequently explained policy shifts with the word 
"adjustment." This is according to the proverb that a wise man will change his mind, but a fool will never do so. China's policy towards Japan has fluctuated between appeasement and firmness. Primarily when the two countries have become too close for economic reasons, the history problem has periodically been brought up to revised policies towards to a harder line. China is fundamentally seeking "profit." If a strong negative effect arises on the domestic economy due to the bottleneck of the territorial issue, it is thoroughly possible that China could turn from principle and shift towards actual benefit.

The problem is in the Japanese side. The major character of Japan's China policy is the maintaining of consistency. What the Japanese diplomatic authorities mostly concern in the 1972 negotiations was how to maintaining consistency with the "fictional" China policy that had existed since the 1950s, which treated Taiwan as a legitimate regime representing all China. ${ }^{17}$ China's diplomacy "changes its mind. " By contrast, Japan cannot.

There is a more serious problem. The 2012 anti-Japanese demonstrations may determine the future course of Japan. Through the fierce criticism of Japan and the violent anti-Japanese demonstrations, Japan's image of China hit rock bottom. Feelings of dislike and of being threatened by "eerie China" and "high-handed China" are spreading through all levels of the Japanese society. Politicians are also leaning towards strengthening defense and making military preparations. An analysis by a private think tank related to the CIA came to the conclusion that a more powerful China and the anti-Japanese demonstrations regarding the Senkaku Islands "may compel Japan to abandon the pacifist stance it has maintained since the end of World War II." ${ }^{\prime 18}$ Still, Japan is generally becoming more conservative and militaristic. The more Japanese militarism is criticized as the historical background to the territory problem, the more Japanese public opinion becomes stiff, conservative, and militaristic those who argue for increased armament rejoice and the bilateral relationship becomes tense. Can China not understand this ironic structure? When Japan abandons "passive pacifism," East Asia will face a new crisis and it will become difficult to avoid a new Cold War. The key may be held by the military presence and political leadership of the US.

The third issue is the severe economic impact of a breakdown of Sino-Japanese relations. The world economy already has global problems, and the Chinese economy is already entering a period of deceleration. Just as the Japan Committee for Economic Development directly pressed the government for improved relations with China in 2005, Japan's economic dependence on China has become

${ }^{17}$ On this point, see Hattori, Ryuji, Nicchu kokko seijoka [Sino-Japanese Diplomatic Normalization] (Tokyo: Chuko Shinsho 2011).

18 "Dispute with China Forces Japan to Rethink Pacifist Stance," LIGNET (1 October 2012) at $<$ http://www.lignet.com/SpecialPages $>$ (searched date: November 4, 2012). 
pressure towards political compromise. Given the current situation, will China, which is sensitive to making profit, take diplomatic initiative to suppress a negative impact on its economy?

\section{A Three-Pronged Emergency Proposal}

Most importantly, an unforeseen military conflict could occur in the East China Sea. This situation must be avoided. This article concludes the following three points as an emergency proposal.

First, in order to avoid an unforeseen collision of fishing boats or maritime patrol vessels, and to prevent the situation if such an unfortunate contingency should occur, a high-level crisis management emergency channel should be established between Japan and China. This is the minimum responsibility that should be fulfilled by the governments in both sides.

Second, the Sino-Japanese relations should start afresh. To do so, at a minimum the following preparation is necessary: (1) Putting the "territorial issue" on the agenda; (2) Restoring the "tacit understanding" over joint development or shelving the territorial issue, and returning to the old state of affairs; (3) Becoming serious about the institutionalization that started in 2006 (This includes the strategic dialogue, the high-level economic dialogue, the security dialogue, and the History Research Committee), and (4) Newly create a comprehensive dialogue mechanism between Japan and China. This would be a dialogue mechanism that assembles the political, economic, cultural, and academic worlds of both sides, and would convene in particular when relations worsen.

Third, in order to create regional public goods, the advanced country of Japan and the economic powerhouse of China should initiate joint actions. This would preferably relate to non-traditional security such as an Asian earthquake measurement and prediction center, an Asian epidemic prevention mechanism, or the concept of Asian emergency foundation. Come to think of it, for the 40 years since normalization of relations, China and Japan have never undertaken a joint eactions that go beyond self-interest and that benefits the region.

There is no doubt that an East Asian Community or an Asia-Pacific Community is the goal of the countries of Asia. But the path towards it is precipitous. The first step is to be made by Japan, China, and South Korea, which lead East Asia, by extricating themselves from boorish nationalism, juvenile populism, and a naked doctrine of national interest. 


\section{References}

Ezra Vogel et al., ed., The Golden Age of the U.S.-China-Japan Triangle, 19721989 (Harvard University Press, Cambridge, 2002).

Shen, Zhihua and Niu, Dayong, eds., Lengzhan yu zhongguo zhoubian guanxi [The Cold War and China's Diplomacy to Neighboring Countries] (Beijing: World Knowledge Publishing House, 2004).

Hattori, Ryuji, Nicchu kokko seijoka [Sino-Japanese Diplomatic Normalization] (Tokyo: Chuko Shinsho, 2011).

Iokibe, Makoto, ed., Sengo nihon gaikoshi [Post-war Japanese Diplomatic History] (Tokyo: Yuhikaku, 2006).

Chinese Information Office of the State Council, Diaoyudao shi zhongguo de guyou lingtu baipishu (September 25, 2012).

Chinese Information Office of the State Council, Zhongguo de heping fazhan baipishu [China's Peaceful Development White Paper] (2011).

Jakobson, et al. (Tatsumi Okabe trans.) Chugoku no Atarashii taigai seisaku [New Foreign Policy Actors in China] (Tokyo: Iwanami Shoten, 2010).

Jin Xide, Zhongri guanxi:Fujiao 30 zhounian de sikao [Sino-Japanese Relations: Thinking after Thirtieth Anniversary of Normalization] (Beijing: World Knowledge Publishing House, 2002).

Lin, Xiaoguang, Riben zhengfu kaifa yuanzhu yu zhongri guanxi [Japan's ODA and Sino-Japanese Relations] (Beijing: World Knowledge Publishing House, 2003).

Mori, Kazuko, Hirano, Kenichiro, eds., A New East Asia-Toward a Regional Community (Singapore: National University of Singapore Press, 2007).

Mori, Kazuko, Nicchu kankei-sengo kara shinjidai e [Sino-Japanese RelationsThe Post-War Towards a New Era] (Tokyo: Iwanami Shoten, 2006).

Oba, Mie, Ajia taiheiyo chiiki Keisei e no michinori [The Journey to the Formation of an Asia-Pacific Region] (Kyoto: Minerva Shobo, 2004).

Pang, Zhongying, Zhongguo yu yazhou—guancha yanjiu pinglun [China and Asia: A Report] (Shanghai: Shanghai Academy of Social Sciences Press, 2004).

Pang, Zhongying, "Xinlang jiu zhongmei zhanlue duihua lianxian guojiwentizhuanjia," [Sina-net interviewed international relations specialists on the issue of Sino-American strategic dialogue] Sina Net (August 1, 2005), at < http://news.sina.com.cn/c/2005-08-01/20557383048.shtml > (searched date: November 11, 2012).

Watanabe, Akio, Ajia taiheiyo no kokusai kankei to Nihon [International Relations of the Asia-Pacific and Japan] (Tokyo: University of Tokyo Press, 2002).

Yan Xuetong, Zhongguo guojia liyi fenxi [An Analysis of China's National Interests] (Tianjin: Tianjin People's Publishing House, 1996). 
Yamamoto, Takehiko, Amako, Satoshi, eds., Higashi Ajia kyodotai no kochiku (1) "Atarashii chiiki keisei" [Building an East Asian Community (1) "Forming a New Region"] (Tokyo: Iwanami Shoten, 2007).

\section{About the Author}

Kazuko MORI is Professor Emeritus at Waseda University. Professor Mori earned her Ph.D. in political science from Waseda University and has been serving as professor at the School of Political Science and Economics at Waseda University since 1999. Her main research interests are the politics and foreign relations of contemporary China. Her major publications include: Politics of Contemporary China: Portrait of the Global Power (Nagoya: Nagoya University Press, 2012) (co-authored) Road to the Global China: Diplomacy of 150 years (Tokyo: Iwanami Publishers, 2009); A New East Asia-Toward a Regional Community, coedited with Kenichiro Hirano (Singapore: National University of Singapore Press 2007); Sino-Japanese Relations: From Post-World War II to the New Stage (Tokyo: Iwanami Publishing, 2006) (in Japanese, Chinese and Korean); Ethno-Nationalism in Contemporary China (Tokyo: University of Tokyo Press, 1998) and The Relationship between the PRC and the USSR (Tokyo: Iwanami Publishing, 1989).

Address: 5-24-3, Nukuikitamachi, Koganeishi, Tokyo, 184-0015, Japan

Email: morika@waseda.jp 